\title{
O próbie zastosowania teorii chaosu do opisu ewolucji obszaru turystycznego
}

\author{
On an attempt at applying chaos theory \\ in describing the evolution of a tourism area
}

\begin{abstract}
LUDWIK MAZURKIEWICZ
Wydział Turystyki i Rekreacji, Akademia Wychowania Fizycznego, 00-345 Warszawa, ul. Marymoncka 34; ztt@awf.edu.pl
\end{abstract}

\begin{abstract}
Zarys treści. Ewolucja obszaru turystycznego rozumiana jest $\mathrm{w}$ artykule jako ciąg następujących po sobie zmian zachodzących w obrębie obszaru przyjmującego podróże turystyczne, dzięki którym jego społeczne życie i gospodarczy charakter podlega przemianom. W literaturze przedmiotu zjawisko to opisywane jest przez koncepcję cyklu życia obszaru turystycznego, uważaną za jedno z najbardziej udanych ujęć teoretycznych w naukach o turystyce. Z prostego początkowo modelu, przekształciła się w ciekawe i rozbudowane narzędzie teoretyczne, zdolne opisywać z coraz większą dokładnością skomplikowany świat zjawisk turystycznych. W artykule przypomniano o najnowszych rozwiązaniach teoretycznych zaadoptowanych przez koncepcję na przestrzeni kilku ostatnich lat, takich jak pojęcie systemu złożonego oraz niektóre założenia teorii chaosu. Te ostatnie wykorzystano do opisu ewolucji jednego z polskich uzdrowisk.
\end{abstract}

Słowa kluczowe: cykl życia obszaru turystycznego, system złożony, teoria chaosu, terytorialny system społeczny, Żegiestów Zdrój.

\section{Wprowadzenie}

Twórcą koncepcji cyklu życia obszaru turystycznego (ang. tourism area life cycle - TALC) jest R.W. Butler (1980). Podobnie jak wiele innych koncepcji stosowanych w naukach społecznych, jest ona wyidealizowanym konstruktem (modelem), prezentującym zespół założeń sformułowanych z myślą o uproszczonym obrazie rzeczywistego świata. Opisuje zatem nie to, co dzieje się w rzeczywistości, lecz to, co zachodzi w wyidealizowanym świecie zjawisk turystycznych. Ponieważ sama koncepcja jest dobrze znana, przedstawiono tylko jej podstawowe założenia.

Koncepcja cyklu życia obszaru turystycznego dotyczy, w oryginalnej wersji, miejscowości turystycznej. Punktem wyjścia jest założenie, że miejscowość 
turystyczna jest produktem, gdyż istnieje rynek, na którym jest sprzedawana. Rynek tworzą wszyscy turyści przyjeżdżający do niej i wydający pieniądze na pobyt i związane z nim korzyści. Upływ czasu oraz przemiany społeczne i gospodarcze wywołane napływem turystów, prezentują ciąg zdarzeń, który nazwano cyklem życia miejscowości turystycznej. Intensywność tego życia mierzona jest za pomocą różnych cech, najczęściej liczby turystów, oprócz której stosowane są także takie zmienne jak: rozmiary inwestycji w infrastrukturę turystyczną, stan środowiska, nastawienie mieszkańców do turystów i turystyki czy struktura turystycznego użytkowania ziemi. W swoim rynkowym życiu miejscowość turystyczna przechodzi przez sześć następujących po sobie faz: eksploracji, zaangażowania (wprowadzenia), rozwoju, konsolidacji i stagnacji. Ta ostatnia faza może zamienić się w fazę upadku bądź odmłodzenia (ryc. 1) (Butler, 1980).

Na rycinie 1 cykl życia obszaru turystycznego przedstawiono posługując się liczbą turystów - zmienną najczęściej spotykaną w literaturze przedmiotu. Fazy cyklu różnią się między sobą tempem zmian tej liczby. Jest ono najwyższe w fazie rozwoju, najniższe zaś w fazie stagnacji; duże może być także w fazie upadku.

Zmianom liczby turystów towarzyszą zmiany rozmiarów inwestycji w zagospodarowanie turystyczne, wielkości zatrudnienia w sektorze turystycznym,

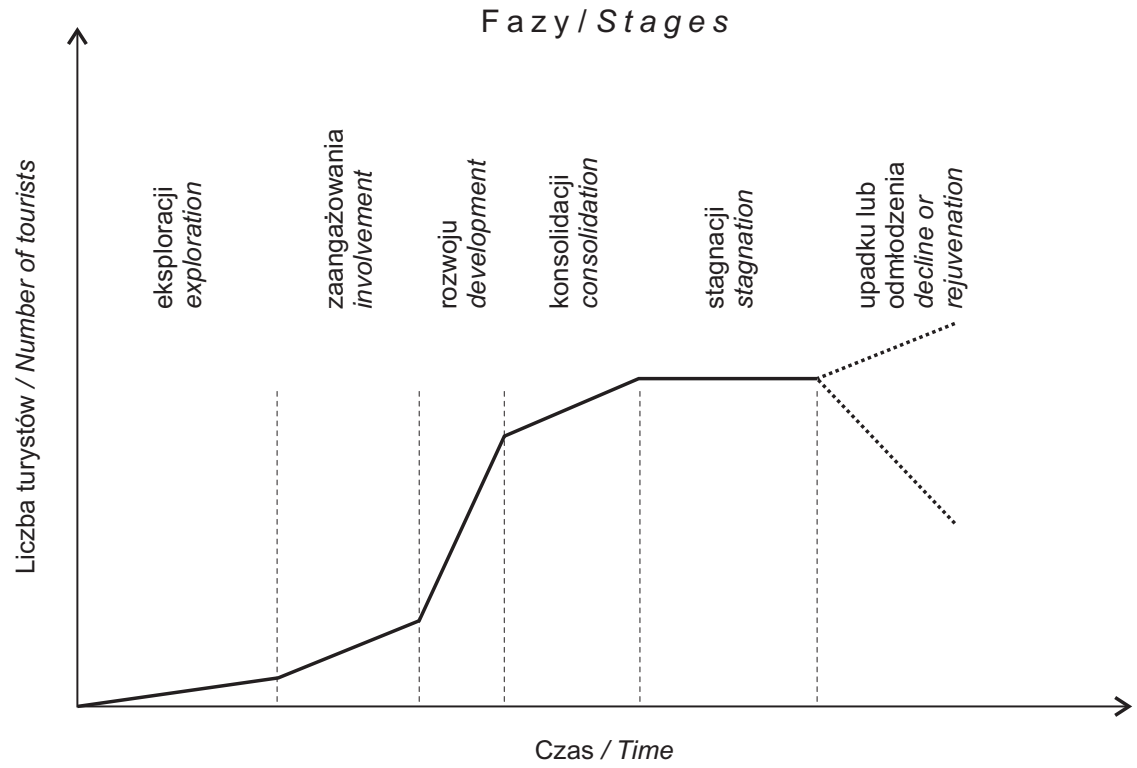

Ryc. 1. Cykl życia obszaru turystycznego Na podstawie: R.W. Butler (1980) - uproszczone.

A tourism area life cycle

Based on: R.W. Butler (1980), simplified. 
rozmiarów zniszczenia środowiska przyrodniczego i poziomu irytacji mieszkańców, w tempie podobnym jak na rycinie 1 .

Jeśli chodzi o zakres przestrzenny, w koncepcji cyklu życia obszaru turystycznego przyjmuje się często, że jest nim miejscowość turystyczna (Butler, 1980; Agarwal, 1997; Oppermann, 1998; Lundtrop i Wanhill, 2001, Szulc-Dąbrowiecka, 2004), bądź większe obszary przyjmujące ruch turystyczny (Cooper i Jackson, 1989; Douglas, 1997; Liszewski i Baczwarow, 1998; Hovinen, 2001). W dalszym ciągu artykułu używa się terminu obszar, przyjmując, że chodzi zarówno o miejscowość, jak i terytorium większe od miejscowości, przyjmujące turystów.

Koncepcja cyklu życia obszaru turystycznego jest w istocie podejściem o deterministycznym charakterze. Ujawnia się ono na dwa sposoby. Po pierwsze, zachodzące zmiany (fazy cyklu życia) pojawiają się zawsze w tej samej kolejności, a wystąpienie jednej determinuje pojawienie się kolejnej, zawsze według tego samego schematu. Przebiegają one prawie liniowo, w tym sensie, że jedna wynika z drugiej i brak jest założenia, że może nastąpić zaburzenie, które spowoduje przerwanie cyklu lub jego zakończenie, czy też ewentualną kontynuację. Po drugie, zmiany przebiegają wyłącznie na makroskalowym poziomie. Dotyczą bowiem zachowania podmiotów zbiorowych (turyści, ludność miejscowa, przedsiębiorcy, infrastruktura turystyczna, środowisko przyrodnicze). Nie uwzględnia się natomiast wpływu czynników działających w sposób przypadkowy, mogących zmienić bieg rzeczy. Takie czynniki pojawić się mogą zarówno na poziomie zachowań indywidualnych (mikroskalowym), jak i w skali makro. Ich brak czyni analizę w dużym stopniu nierealną, odrywa bowiem obszar od otoczenia, w którym zachodzą procesy mogące mieć wpływ na cykl jego życia. Założenie o braku wpływu zjawisk w zewnętrznym otoczeniu obszaru turystycznego dodatkowo upraszcza i zuboża analizę.

Początkowe założenia, na których oparta została koncepcja, były z biegiem czasu stopniowo uchylane i zastępowane nowymi, lepiej odzwierciedlającymi turystyczną rzeczywistość. Ich przegląd i omówienie można znaleźć w jednej z ostatnich prac R.W. Butlera (2006a, b). W niniejszym artykule omówiono dwa nowe założenia (rozwiązania teoretyczne) zaproponowane stosunkowo niedawno w literaturze przedmiotu: pojęcie systemu złożonego oraz niektóre podstawowe założenia teorii chaosu. Przykład zastosowania tych ostatnich zawiera końcowa część tekstu.

\section{Systemy złożone i teoria chaosu}

Pojęcie systemu złożonego staje się bardziej zrozumiale, gdy poprzedzi się je wyjaśnieniem, czym był system w ujęciu obowiązującym przed pojawieniem się jego złożonej wersji. 
Pojęcie systemu wprowadził do nauki austriacki uczony L. Bertalanffy (1951, 1984). Wyróżnił dwa podstawowe rodzaje systemów: zamknięte i otwarte. Te pierwsze nie podlegają wpływowi zmian zachodzących w ich otoczeniu, to znaczy nie wymieniają z nim materii, energii i informacji; powoduje to wzrost stanu ich wewnętrznego nieuporządkowania (entropii), prowadzącego w rezultacie do degeneracji i zaniku. Systemy otwarte z kolei - to takie, które pozostają w kontakcie ze swoim otoczeniem i wymieniając z nim materię, informację i energię, zdolne są do podtrzymywania i przedłużania własnej egzystencji. W dalszym ciągu używając terminu system będziemy zawsze mieli na myśli system otwarty.

Istota pojęcia systemu zawiera się w prostym stwierdzeniu, że jest to zbiór elementów oraz relacji między nimi, sprawiających, że każda zmiana stanu elementu lub elementów znajduje skutek w postaci zmian stanu innych elementów systemu (Bertalanffy, 1984). Z uwagi na swój skład, system prezentuje hierarchiczną naturę w sensie występowania różnych poziomów uogólnienia (agregacji). To, co jawi się jako element systemu na jednym poziomie, przyjmuje postać systemu na poziomie niższym i, konsekwentnie, każdy z jego elementów prezentuje odrębny system na jeszcze niższym poziomie. Umożliwia to przechodzenie od wyższej, a więc mniej dokładnej skali analizy do niższej, bardziej skomplikowanej. System jest więc z definicji układem złożonym, wieloskalowym.

Pojęcie systemu złożonego nie odnosi się jednak do stopnia skomplikowania jego struktury, lecz do zachowania tego systemu. Jeśli chodzi o omówione wcześniej systemy, zakładano, że zachowują się one stabilnie, tj. że w dostatecznie dużym stopniu dawało się przewidywać ich zachowanie. Rządził nimi deterministyczny, a dokładniej redukcjonistyczny porządek. Redukcjonizm oparty jest na przekonaniu, że istnienie zarówno systemów, jak i ich własności, jest sprowadzalne do istnienia i własności ich części. Oznaczało to nic innego jak to, że zachowanie systemów daje się wyprowadzać z zachowania ich elementów, a więc da się opisywać i wyjaśniać w samych jedynie kategoriach zachowania elementów składających się na system (Prigogine i Stengers, 1985). Każde zdarzenie w ramach systemu było zdeterminowane przez określone warunki początkowe i dawało się przewidywać, jeśli tylko znany był charakter relacji między elementami. Analiza badawcza sprowadzała się więc do poznania natury tych relacji oraz sposobu, w jaki zmieniały się stany elementów pod ich wpływem. Podstawowe było założenie o liniowym charakterze związków między elementami: niewielkim zmianom początkowym odpowiadały niewielkie zmiany końcowe, i na odwrót, dużym zmianom - odpowiednio duże zmiany końcowe. Drugie, nie mniej ważne, było założenie o tendencji systemu do osiągania stanu równowagi. Takie zachowanie było możliwe dzięki przewadze relacji o charakterze ujemnego sprzężenia zwrotnego, tłumiących wszelkie zmiany o narastającym natężeniu. Zachowanie systemów charakteryzowała więc stabilność, porządek i równowaga. Wszelkie przejawy braku stabilności, porządku i równowagi trak- 
towane były jako przypadkowe odchylenia od normy, stanowiące raczej wyjątek niż regułę (Prigogine i Stengers, 1985).

Odkrycia w obszarze fizyki zaczęły jednak dostarczać innych wniosków. Coraz częściej zaczęły pojawiać się dowody na to, że rzecz ma się zgoła inaczej. Ku zdumieniu naukowców, to właśnie niestabilność, nieporządek i nierównowaga okazywały się być normą, a stabilność, porządek i równowaga - tylko szczególnym stanem w obszarze występowania tych pierwszych. Do opisu tej normy nie wystarczało jednak założenie o stabilnym zachowaniu systemów. Konieczne było stworzenie nowej idei systemu, opartej na zupełnie innych założeniach. Uosabiało ją pojęcie systemu złożonego. O ile w omawianych poprzednio systemach stabilnych relacje miały liniowy charakter, o tyle w systemach złożonych (niestabilnych) mają one naturę nieliniową. Małe zmiany stanu określonego elementu lub elementów wywoływać mogą nieproporcjonalnie duże zmiany stanu innych elementów. Dzieje się tak dzięki przewadze relacji o charakterze dodatniego sprzężenia zwrotnego, wzmacniających natężenie pojawiających się zmian. Nawet niewielka zmiana stanu jakiegoś elementu może wywołać skutek odbijający się na stanie wielu elementów czy wręcz całego systemu. Przysłowiowy stał się już (hipotetyczny) przykład podany po raz pierwszy przez E. Lorenza, znany jako efekt motyla, mający stanowić przykład sytuacji, gdy niewielka, wręcz niezauważalna zmiana (perturbacja) wywołuje reakcję łańcuchową, której kulminacją jest wręcz niespotykane w swych rozmiarach zjawisko czy diametralna zmiana w strukturze systemu. To tak, jakby zmiana ciśnienia powietrza spowodowana ruchem skrzydeł motyla fruwającego w lesie amazońskim, przeniesiona i wzmacniana przez specyficzne zależności w atmosferze, spowodowała pojawienie się tornado $\mathrm{w}$ Teksasie. W systemie stabilnym, niewielka zmiana wywołuje najczęściej podobny, niewielki skutek, ponieważ wszelkie odchylenia są tłumione przez mechanizm ujemnego sprzężenia zwrotnego, co w rezultacie powoduje, że system stale dąży do stanu dynamicznej równowagi. Zachowanie systemu złożonego (niestabilnego) charakteryzują tymczasem następujące po sobie okresy turbulencji (zaburzeń) oraz powrotu do stanu stabilności (Tempczyk, 1998).

Do opisu zachowania systemu złożonego, wykazującego niestabilny i turbulencyjny charakter konieczna była teoria pozwalająca ogarnąć i wyjaśnić to zachowanie. Taką okazała się teoria chaosu.

Sama nazwa „chaos” kojarzy się z procesem narastania nieporządku i dezorganizacji, zmierzającym do rozpadu istniejącej struktury i nieuchronnego końca tego, co jeszcze do niedawna istniało. Tymczasem, według teorii, chaos jest pewnym specyficznym etapem czy też stanem zachowania się systemu. System wchodzi w okres chaosu bądź na skutek zmian w otoczeniu, bądź pod wpływem jakiejś wewnętrznej zmiany. Chaos nie jest jednak destrukcyjny. Wręcz odwrotnie: pojawiające się zaburzenia stanowią reakcję na zmianę (bodziec), która zaszła, system jednak dostosowuje swoje zachowanie do nowych warunków 
i przyjmuje, czy też osiąga nowy stan organizacji. W tym sensie, chaos lub chwilowy stan dezorganizacji nie ma destrukcyjnego charakteru - prowadzi raczej do innego, nowego i bardziej złożonego porządku (Prigogine i Stengers, 1985).

Chaos w systemie złożonym nie jest jednak, jak mogłoby się wydawać, czymś co może pojawić się zupełnie nieoczekiwanie. Tak może być odbierany przez obserwatorów z zewnątrz. W rzeczywistości istnieje pewna kolejność zdarzeń, właściwa niestabilnej naturze systemu. Jak już wspomniano, zachowanie systemu złożonego charakteryzuje następowanie po sobie okresów stabilności i zaburzeń (chaosu). Osiągnąwszy stabilność, system może przebywać w tym stanie tak długo, jak długo nie pojawi się czynnik zaburzający jego funkcjonowanie. Może to być czynnik pochodzący z otoczenia lub działający wewnątrz systemu. Powoduje on, w zależności od siły swego oddziaływania, że system zaczyna, wolno lub szybko, tracić stabilność. W nomenklaturze teorii chaosu, określa się to jako odchodzenie od stanu równowagi i im dłużej trwa ten proces, tym bardziej system zbliża się do tzw. granicy chaosu (ang. edge of chaos), po przekroczeniu której zaczyna zachowywać się w sposób chaotyczny. Po przejściu przez fazę chaosu system wraca do stanu równowagi, jednak porządek jaki prezentuje w nowym stanie różni się od tego, który prezentował poprzednio. Skłonność do przechodzenia na przemian przez stany równowagi i stany chaosu oraz towarzysząca jej tendencja do zmian organizacji systemu sprawiają, że zachowanie systemu złożonego, o czym już wcześniej wspomniano, rzadko poddaje się uznanym regułom opisu i wyjaśniania i jest niezwykle trudne do przewidzenia. Jest to chyba najbardziej podstawowa cecha różniąca systemy złożone i stabilne (McDonald, 2009).

Zanim przejdziemy do omówienia pojęcia systemu złożonego oraz podstawowych założeń teorii chaosu w odniesieniu do zjawiska ewolucji obszaru turystycznego, warto poświęcić kilka słów innemu jeszcze pojęciu - pojęciu samoorganizacji, jednemu z najważniejszych w teorii. Wywodzi się ono z fizyki (termodynamiki), w odniesieniu jednak do dużo bardziej skomplikowanych zjawisk społecznych zapożyczone zostało z nauk biologicznych, a dokładniej z rozważań nad zjawiskami ekologicznymi (McKercher, 1999).

Samoorganizacja jest właściwością systemu złożonego, dzięki której, po okresie chaosu, system wraca do stanu równowagi, osiągając przy tym nowy stan organizacji struktury. Jest to właściwość, która pozwala spontanicznie i adaptacyjnie rozwijać lub zmieniać wewnętrzną strukturę systemu tak, aby dostosować ją do zmieniających się warunków otoczenia lub wręcz oddziaływać na nie. Zmiany powodujące pojawianie się stanu równowagi nie wynikają z jakiegoś z góry założonego planu, nie są też konsekwencją jakichś szczególnych właściwości elementów. Jak już wspomniano, mają żywiołowy i spontaniczny charakter, a ich źródłem jest złożony układ interakcji między elementami systemu. Łączą one dwa podstawowe poziomy hierarchicznej struktury systemu - mikroskalowy i makroskalowy. Ważną właściwością (samoorganizującego się) systemu złożo- 
nego jest jego zdolność do zapamiętywania własnej historii, a więc pamięć. Bez tej właściwości system byłby zdolny jedynie do biernego odzwierciedlania zmian zachodzących w otoczeniu (Prigogine i Stengers, 1985).

\section{Obszar turystyczny jako system złożony}

Obszar turystyczny wraz z jego zawartością społeczno-ekonomiczną, traktować należy jako system złożony. W swej istocie stanowi on przykład tego, co w naukach społecznych nosi nazwę terytorialnego systemu społecznego. To ostatnie pojęcie wprowadził do literatury geograficznej Z. Chojnicki (1988). Przedstawiony niżej opis tego systemu opiera się w całości na jego opracowaniu.

Terytorialny system społeczny jest związany ze zbiorowością ludzi, którzy zajmują, kontrolują i zagospodarowują określone terytorium. „Właściwa charakterystyka terytorialnego systemu społecznego wymaga rozpatrzenia jego podstawowych aspektów, tj. składu, otoczenia i struktury" (Chojnicki, 1988, s. 498).

Skład systemu tworzą: zbiorowość ludzi oraz terytorium, które oni zajmują. Ludzie są elementarnymi składnikami zbiorowości. Prowadzona przez nich działalność sprawia, że wchodzą w relacje z innymi ludźmi tworząc różne grupy społeczne, które powstają i istnieją na bazie powiązań o charakterze społecznego podziału pracy. Grupy te składają się na rozmaite systemy działalności, które dają się sprowadzić do trzech podstawowych: ekonomicznego, kulturowego i politycznego.

W ramach terytorium zajmowanego przez zbiorowość ludzi wyróżnić można dwa rodzaje obiektów: przyrodnicze i sztuczne. Te pierwsze stanowią środowisko przyrodnicze, które podzielić można na organiczne, składające się na świat przyrody ożywionej i nieorganiczne, stanowiące jej materialne podłoże. Sztuczne obiekty materialne stanowią bazę materialną i infrastrukturalną ludzkiej działalności i egzystencji. Opierając się na niej funkcjonują wspomniane wcześniej trzy systemy społecznej działalności: ekonomiczny, kulturowy i polityczny.

Tak rozumiany terytorialny system społeczny ma określoną strukturę, wyznaczoną przez relacje i związki między składnikami. „Podstawowymi relacjami tworzącymi strukturę terytorialnego systemu społecznego są: (1) relacje i działania społeczne, (2) relacje i działania transformacyjne, (3) oddziaływania przyrodniczo-ekologiczne" (Chojnicki, 1988, s. 504).

Relacje i działania społeczne zachodzą między ludźmi, ich grupami oraz podsystemami społecznymi. „Relacje i działania społeczne obejmują: a) relacje pochodzenia biologicznego i oparte na nich relacje pokrewieństwa, b) relacje komunikowania się przy pomocy określonego języka lub kodu, c) relacje dostępu do dóbr i usług, d) relacje uczestnictwa w działalności społecznej, oraz e) relacje zarządzania i kontroli” (tamże, s. 504).

Relacje i działania transformacyjne dzielą się na trzy podstawowe rodzaje: pracę produkcyjno-materialną, pracę kulturalną i pracę kierowniczo-admini- 
stracyjną. Ta pierwsza polega na wytwarzaniu dóbr materialnych i usług oraz ich przemieszczaniu, druga, na kształtowaniu ludzkich umysłów lub uczuć ludzi przy użyciu dóbr kulturalnych i usług (np. nauczanie), trzecia natomiast na „kierowaniu, zarządzaniu, planowaniu, organizowaniu i kontrolowaniu działalnością ludzi. [...] Rola poszczególnych rodzajów pracy [...] w działalności ludzi stanowi podstawę wyodrębnienia głównych podsystemów występujących w ramach każdego terytorialnego systemu społecznego tj. gospodarki, kultury i systemu politycznego" (jw., s. 505).

Oddziaływania przyrodniczo-ekologiczne dotyczą wzajemnego wpływu ludzi i środowiska przyrodniczego związanego z terytorium, na którym żyją.

Obok składników systemu i jego struktury, trzecią rzeczą, która go charakteryzuje, jest otoczenie. O otoczeniu terytorialnego systemu społecznego mówi się w dwojakim sensie: wewnętrznym i zewnętrznym. W tym pierwszym przypadku, otoczeniem jest środowisko zbiorowości ludzi, a więc wspomniane już właściwe dla terytorium środowisko przyrodnicze oraz środowisko sztuczne (antropogeniczne) złożone ze sztucznych obiektów, wytworzonych lub ukształtowanych w wyniku celowej działalności ludzi. Otoczeniem zewnętrznym są inne terytorialne systemy społeczne „tego samego rzędu lub poziomu, z którymi dany system jest powiązany wzajemnymi oddziaływaniami” (Chojnicki, 1988, s. 502). „Terytorialne systemy społeczne występują na kilku poziomach rzeczywistości społecznej: (1) lokalnym, (2) regionalnym, (3) krajowym, (4) ponadkrajowym oraz (5) globalnym" (tamże, s. 507).

Na każdym z tych poziomów, terytorialny system społeczny jawi się jako system złożony. Poniżej przedstawiono najbardziej charakterystyczne cechy takiego systemu (opracowanie własne na podstawie: McDonald, 2009):

1) składa się on z dużej lub bardzo dużej liczby elementów, w znacznej części bardzo aktywnych, w sensie wpływu wywieranego na inne elementy usytuowane bliżej lub dalej; przykładem są przedsiębiorcy czy ludzie związani z władzą lub zarządzaniem;

2) jak wynika z wcześniejszego opisu jego organizacja jest hierarchiczna i wieloszczeblowa; systemy lokalne, prezentujące własną strukturę hierarchiczną, wchodzą w skład większych systemów, które z kolei stanowią składowe jeszcze większych systemów terytorialnych;

3) cechuje go zdolność do samoorganizacji - mając wbudowane układy zarządzania i kontroli, zdolny jest do adaptacji do nowych warunków;

4) jego samoorganizacja opiera się na jeszcze jednej właściwości - jest nią zdolność do zapamiętywania własnej historii, a więc posiadanie pamięci, która sprzyja i pomaga w wyborze właściwego rodzaju zachowań adaptacyjnych;

5) dużej liczbie elementów składających się na system towarzyszy wielokrotnie większa liczba relacji i powiązań między nimi; są to nie tylko relacje wewnątrz systemu, ale także te, które wiążą go z otoczeniem; mają one najczęściej nieliniową naturę, co decyduje o nieprzewidywalności wywołanych 
za ich pośrednictwem efektów i stanowi podstawową przyczynę tego, że nadzwyczaj trudne jest przewidywanie nawet niedalekiej przyszłości systemu;

6) jest niestabilny w tym sensie, że potrafi funkcjonować w warunkach dalekich od stanu równowagi, który wcale nie jest dominującym w jego zachowaniu; przebywa najczęściej w przedziale między nim a stanem chaosu;

7) niestabilności czy też zaburzenia w systemie mogą być wywołane zarówno przez zmiany zachodzące w otoczeniu, jak i zmiany wewnątrz systemu; zmiany te mogą mieć różną skalę, ale nawet jeżeli są niewielkie, to dzięki nieliniowej naturze relacji, mogą wywoływać nieraz niespodziewane skutki.

Zastosowanie koncepcji cyklu życia obszaru turystycznego do opisu zachowania systemu złożonego, jakim jest taki obszar jest niewystarczające. Koncepcja jest przykładem wspomnianego już redukcjonistycznego podejścia, które zakłada, że system, jakim jest turystyczny obszar wraz z jego społeczną i ekonomiczną zawartością, zachowuje się tak, aby zapewnić utrzymanie równowagi dynamicznej (zachowanie jej w czasie). Zachowanie tej równowagi jest możliwe dzięki liniowemu charakterowi interakcji zachodzących w systemie. Dzięki nim ewolucja systemu (życie rynkowe obszaru) przebiega również w sposób liniowy (przewidywalny). Charakterystyczne dla koncepcji założenie o liniowym, a właściwie prawie liniowym, przebiegu zmian mówi o tym, że przechodzenie z jednej fazy do następnej nie tylko następuje w sposób ciągły, bez zaburzeń, ale co najważniejsze daje się przewidywać. Tymczasem rzeczywistość nie potwierdza tego przekonania. Przede wszystkim zachowanie systemu nie jest przewidywalne - to wynika z faktu, że przejście z fazy do fazy wcale nie jest z góry zapewnione i że obszar niekoniecznie musi w swoim życiu „zaliczyć” wszystkie fazy swojego rozwoju. Jego rozwój może ulec zakończeniu w dowolnej fazie, zatem przejście do następnej fazy zostanie przerwane i obszar zakończy swoje rynkowe życie. Może także, gdy nastąpi spadek aktywności w którejkolwiek fazie, wrócić na ścieżkę wzrostu i proces rozwoju będzie kontynuowany.

\section{Przykład zastosowania teorii chaosu do opisu ewolucji obszaru turystycznego}

Skomplikowany charakter przebiegu zmian w życiu obszaru turystycznego, niedający się opisać liniowym modelem spowodował, że sięgnięto po teorię chaosu. Przypadek cyklu życia obszaru turystycznego jest pierwszym przykładem zastosowania tej teorii w turystyce (McKercher, 1999; Russell i Faulkner, 1999, 2004; Farrell i Twinning-Ward, 2005). Przykładów takich jest jednak wciąż niewiele. Powodem jest trudność, która dotyczy w ogóle badań nad cyklem życia obszaru. Jest nią najczęściej bardzo długi okres, dla którego należy zebrać dane empiryczne (Hovinen, 2001). Wynosi on co najmniej kilkadziesiąt lat. W dalszej części tekstu przedstawiono przykład spełniający ten warunek. Opi- 
sane zmiany pokazano z punktu widzenia teorii cyklu życia obszaru turystycznego uzupełnionej o założenia teorii chaosu.

Przykład dotyczy Żegiestowa-Zdroju, jednego z uzdrowisk na południu Polski. Jest to niewielka miejscowość, położona w Beskidzie Sądeckim u zbiegu Popradu i Szczawnika. Do jej walorów zalicza się korzystny mikroklimat oraz źródła wód mineralnych przydatnych w leczeniu m.in. chorób układów trawienia i krążenia. Zmiany zachowania systemu turystycznego związanego z obszarem uzdrowiska pokazano na rycinie 2 (ikony symbolizujące wybuchy oznaczają stany chaosu - każdy zaczyna się w końcowym momencie fazy upadku i kończy w momencie pojawienia się fazy wzrostu).

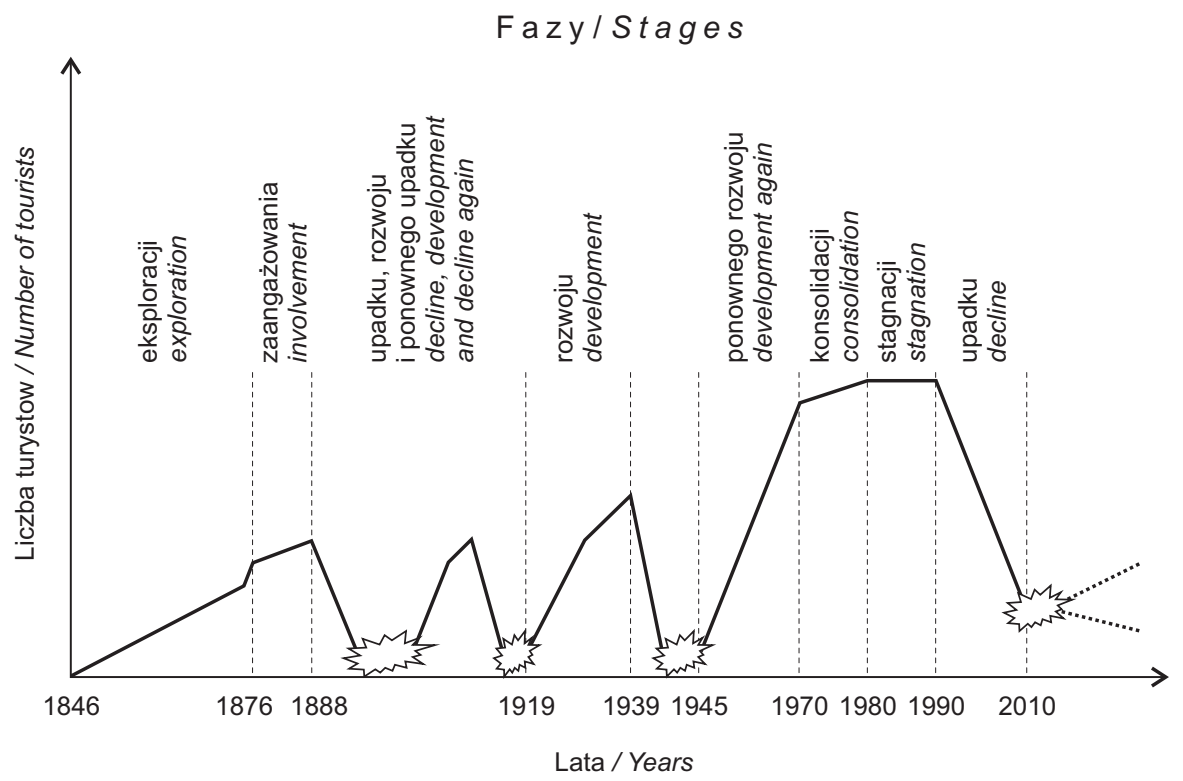

Ryc. 2. Cykl życia uzdrowiska Żegiestów-Zdrój

Opracowanie własne na podstawie: Z. Kruczek, P. Zmyślony (2010, s. 29).

The Żegiestów Spa life cycle

Author's own elaboration based on: Z. Kruczek and P. Zmyślony (2010, p. 29).

Kuracjusze pojawili się w Żegiestowie w połowie XIX w., dając początek fazie eksploracji. Gości przyciągały nie tylko malownicze miejsce i sprzyjający klimat, ale także odkrycie pierwszego źródła w 1846 r. przez J. Medweckiego, który jako jego właściciel stał się (wspólnie z bratem) pierwszym przedsiębiorcą w zdrojowisku, trudniąc się między innymi sprzedażą butelkowanej wody mineralnej. Wkrótce pojawiło się kąpielisko i pierwsze domy dla turystów (Kruczek i Zmyślony, 2010, s. 25). 
Faza eksploracji przeszła w fazę zaangażowania (wprowadzenia) z chwilą otwarcia kolei tarnowsko-leluchowskiej i zlokalizowania przystanku kolejowego w Żegiestowie-Zdroju w 1876 r. Spowodowało to większy napływ turystów. Zbudowano nowy, większy dom zdrojowy, pijalnię wód mineralnych, pojawiły się wille przyjmujące gości. Kuracjuszy, a także letników, obok pięknych widoków, przyciągało również kąpielisko nad Popradem (jw., s. 25).

W roku 1888 umiera właściciel, K. Medwecki. Jego brak jako dobrego zarządcy oraz spory spadkobierców, a także klęski żywiołowe, pożary pensjonatów i katastrofy budowlane doprowadzają do upadku zdroju (Kruczek i Zmyślony, 2010, s. 25). Śmierć właściciela i brak właściwego zarządzania sprawiają, że $\mathrm{w}$ zachowaniu systemu pojawia się tendencja do przesuwania w kierunku chaosu. Jego pojawienie przyspieszają pozostałe niekorzystne zdarzenia, a punktem kulminacyjnym stał się moment, kiedy spadkobiercy sprzedali zdrojowisko.

Krótki okres rozwoju rozpoczął się w 1906 r., po zakupieniu zdroju przez nowych właścicieli - W. Więckowską i księdza dr. M. Żygulińskiego). Odbudowano zniszczone obiekty, powstała nowa dzielnica willowa, zainwestowano w nowe centrum. Założono wodociągi, wprowadzono oświetlenie elektryczne, pojawiła się poczta, apteka i czytelnia (tamże, s. 25). Po okresie chaosu system wszedł w fazę rozwoju, wracając do stanu równowagi i prezentując przez stosunkowo krótki czas, nowy porządek. Czynnikiem, który ponownie wytrącił system ze stanu równowagi okazała się I wojna światowa. Działania wojenne, spustoszenie i związane z nią zniszczenia spowodowały upadek zdroju (tamże, s. 25). System znalazł się powtórnie w fazie chaosu.

Po zakończeniu wojny uzdrowisko nabyli nowi właściciele, tworząc „Spółkę z ograniczoną odpowiedzialnością „Żegiestów-Zdrój” z siedzibą w Krakowie. Spółka zajęła się prowadzeniem istniejących zakładów zdrojowych" (Kruczek i Zmyślony, 2010, s. 26). W roku 1923 „...uznano Żegiestów za zdrojowisko o charakterze użyteczności publicznej, a Ministerstwo Zdrowia Publicznego wydało zarządzenie dotyczące ochrony górniczej zasobów mineralnych w Żegiestowie. Powołano Komisję Zdrojową i opracowano statut uzdrowiska. Dzięki temu zdrój otrzymał dotację i kredyty państwowe, mimo że był własnością prywatną. Dzięki tym kredytom i subwencjom rozpoczęto na szeroką skalę rozbudowę uzdrowiska" (tamże, s. 26). Zakończenie działań wojennych, a także zmiany o charakterze prawnym, stanowiące klasyczny przykład uruchomienia mechanizmu samoorganizacji, zakończyły okres chaosu i sprawiły, że system wszedł w fazę rozwoju. Rozbudowywane i unowocześniane uzdrowisko przyjmowało coraz więcej gości.

Wybuch II wojny światowej wprowadził system kolejny raz w stan chaosu. Po jej zakończeniu, uzdrowisko zostało odbudowane, a następnie upaństwowione. „W 1948 r. w Krynicy powołano Okręgową Dyrekcję Uzdrowisk Karpackich, w składzie których znalazł się Żegiestów-Zdrój, a w 1963 r. powstało Państwowe Przedsiębiorstwo Uzdrowiskowe Krynica-Żegiestów-Zdrój” (jw., s. 27). 
Leczenie uzdrowiskowe stało się bezpłatne, dostępne dla każdego obywatela, powodując masowy napływ turystów do miejscowości. System ponownie wszedł w fazę rozwoju.

„Lata siedemdziesiąte to dynamiczny rozwój uspołecznionej bazy noclegowej, piętnaście zakładów pracy wybudowało tu swoje domy wczasowe lub adaptowało do tych celów istniejącą, choć mocno zdewastowaną bazę. W bazie tej skupione było 75\% miejsc noclegowych uzdrowiska. [...] Frekwencję kuracjuszy i wczasowiczów obliczano na 15 tysięcy osób rocznie. [...] Liczba gości znacznie przewyższyła liczbę mieszkańców, a usługi turystyczne stały się dla mieszkańców głównym źródłem utrzymania" (Kruczek i Zmyślony, 2010, s. 27). System wszedł $\mathrm{w}$ fazę konsolidacji, $\mathrm{z}$ charakterystycznym spadkiem tempa wzrostu przyjazdów, związanym ze zbliżaniem się do pułapu pojemności obszaru. Kryzys lat osiemdziesiątych spowodował wejście systemu w fazę stagnacji. Z kolei lata dziewięćdziesiąte zaznaczyły się w skali całego kraju wzrostem zainteresowania i rosnącą popularnością wyjazdów zagranicznych. W rezultacie zaczęła spadać liczba turystów odwiedzających Żegiestów-Zdrój. Sytuację pogorszył problem reprywatyzacji uzdrowiska oraz nieuregulowane stosunki własnościowe (tamże, s. 28). Faza konsolidacji zamieniła się w fazę spadku. System zaczął zmierzać w kierunku granicy chaosu. Jego widomymi oznakami, podobnie zresztą jak w większości polskich uzdrowisk, stały się spadek liczby kuracjuszy i turystów przybywających do zdrojowiska, opuszczone lub tylko częściowo wypełnione budynki sanatoryjne, zdekapitalizowana baza noclegowa i usługowa, niska jakość usług, niskie ceny kwater i rosnące bezrobocie wśród mieszkańców.

Wyjście ze stanu chaosu jest możliwe poprzez uruchomienie mechanizmu samoorganizacji. Może mieć on postać decyzji podejmowanych na zewnątrz (w otoczeniu systemu), np. przez władze zainteresowane rozwojem usług uzdrowiskowych, bądź zostać wywołany decyzjami wynikającymi z inicjatywy lokalnej. Przykłady uaktywnienia tej ostatniej mają już miejsce. „Wznowiło swoją działalność Towarzystwo Przyjaciół Żegiestowa dbające m.in. o promocję kurortu i wspierające działania inwestycyjne. Wykonano wiele inwestycji w zakresie rewitalizacji uzdrowiska [...]" (jw., s. 27). Działania tego typu mogą przynieść skutek w postaci uaktywnienia funkcji uzdrowiskowej i powrotu kuracjuszy, a więc wejścia systemu w fazę odmłodzenia, co zaznaczono na rycinie 2 wznoszącą się linią przerywaną. Brak aktywności o charakterze samoorganizacyjnym może natomiast spowodować pogłębianie chaosu, czego wyrazem jest opadająca linia przerywana. Ta druga sytuacja wydaje się jednak dużo mniej prawdopodobna. Wynika to z podstawowego założenia dotyczącego zachowania adaptacyjnych systemów złożonych, zgodnie z którym, dzięki samoorganizującej się naturze, potrafią dostosować się do zmian i przedłużyć swoje życie jeśli tylko dysponują odpowiednimi zasobami, w omawianym przypadku o charakterze walorów przyciągających turystów. 
Zachowania systemu turystycznego związanego z kurortem nie można opisać i wyjaśnić w kategoriach klasycznej teorii cyklu życia obszaru turystycznego opartej na założeniu o (quasi)liniowości zachodzących zmian. Takie założenie ma sens tylko wtedy, gdy przyjmie się, że procesy zachodzące w otoczeniu lub w mikroskali systemu nie wywierają wpływu na jego życie rynkowe. Te ostatnie procesy nie są zresztą uwzględniane, ponieważ jak już wspominano, teoria cyklu życia obszaru turystycznego dotyczy zjawisk zachodzących jedynie w skali makro. Tymczasem, jak wynika z przedstawionego przykładu, wpływ otoczenia i zmian w samych systemach, także na poziomie działań jednostkowych, potrafi zmieniać bieg rzeczy. To właśnie on sprawia, że cykl życia obszaru turystycznego nie ma liniowej (przewidywalnej) postaci, a jego przebieg jest niezwykle trudny do odgadnięcia; wyrazem tego jest nieciągły i niestabilny przebieg zmian.

Jak widać, założenia teorii chaosu dodane do teorii cyklu życia obszaru turystycznego sprawiają, że lepiej jest dostosowana do opisu rzeczywistości. Jej podstawową zaletą jest zdolność odwzorowywania nieliniowego przebiegu zdarzeń oraz wyjaśniania przyczyn odpowiedzialnych za pojawiający się stan rzeczy. Dzięki niej jedna z najważniejszych, a na pewno najbardziej rozpowszechnionych teorii turystycznych stała się bogatsza o nowe, ciekawe założenia oraz zwiększyła swą siłę - zarówno opisową, jak i wyjaśniającą.

\section{Zakończenie}

Koncepcja cyklu życia obszaru turystycznego, podobnie jak wiele innych koncepcji stosowanych w naukach społecznych, jest zespołem założeń sformułowanych z myślą o skrajnie uproszczonym obrazie rzeczywistego świata. W turystyce uważana jest za jedno z najbardziej udanych ujęć teoretycznych. Stanowi popularne narzędzie opisu i wyjaśniania zmian społecznych i gospodarczych, zachodzących w obrębie obszaru przyjmującego podróże turystyczne. Z przykładów zawartych w literaturze przedmiotu wynika jednak, że im dokładniejsze są dane empiryczne i w związku z tym, wymagany dokładniejszy opis, koncepcja gorzej sobie radzi z uchwyceniem przebiegu zdarzeń. Trudno się jednak dziwić - jak już wspomniano, stworzona została po to, żeby zdawać sprawę nie z tego co dzieje się w rzeczywistości, ale co zachodzi w ramach uproszczonego obrazu tej rzeczywistości. Ten uproszczony obraz przyjmuje, zgodnie z koncepcją, postać systemu, którego elementami są podmioty zbiorowe (mieszkańcy, turyści, przedsiębiorcy inwestujący w sektor turystyczny, zatrudnieni w tym sektorze) związane z określonym obszarem oraz relacje między nimi. W odniesieniu do tak rozumianego systemu przyjęto dwa podstawowe założenia upraszczające: (1) jest on zamknięty, a więc odizolowany od zewnętrznego otoczenia i zmian w nim oraz (2) zachowanie systemu analizowane jest w ujęciu makroskalowym, z punktu widzenia związków między wymienionymi podmiotami zbiorowymi, 
bez uwzględnienia wpływu zachowań na poziomie mikroskalowym, ujawnianych przez jednostki ludzkie.

Zachowanie systemu opisane jest w koncepcji za pomocą krzywych prezentujących zmiany wartości zmiennych odnoszących się do poszczególnych podmiotów zbiorowych i relacji między nimi. Kształt czy przebieg tych krzywych nie oddaje jednak tego, co dzieje się w rzeczywistości, lecz to, co zachodzi w systemie, odwzorowującym w sposób uproszczony tę rzeczywistość. Aby poprawić dopasowanie krzywych, w naszym przypadku linii opisującej liczbę przyjeżdżających turystów, należy skomplikować uproszczony świat, prezentowany w koncepcji przez system, i właśnie to uczyniono w artykule. Zachowanie systemu poddano komplikacji poprzez uchylenie obydwu założeń upraszczających. Przyjęto zatem, że zachowanie to podlega wpływowi zmian zewnętrznych oraz że zmiany mogą zachodzić na obydwu poziomach uogólnienia jego struktury: makro- i mikroskalowym. Problem polega jednak na tym, że przyjęte nowe założenia wychodzą poza te, na których opiera się dotychczasowa koncepcja, co sprawia, że nie jest ona zdolna uchwycić wpływu zewnętrznych zmian oraz zachowań pojedynczych ludzi. Za nowymi założeniami powinna iść nowa teoria - i taka właśnie jest teoria chaosu. Po uzupełnieniu przez nią dotychczasowej koncepcji, stało się możliwe uchwycenie wpływu bodźców zewnętrznych i zmian na poziomie mikroskalowym, a w rezultacie lepsze dopasowanie linii opisującej zachowanie systemu do rzeczywistych zdarzeń.

\section{Piśmiennictwo}

Agarwal S., 1997, The resort cycle and seaside tourism: An assessment of its applicability and validity, Tourism Management, 18, 1, s. 65-73.

Bertalanffy von L., 1951, An outline of general system theory, British Journal of the Philosophy of Science, 1, s. 134-165.

Bertalanffy von L., 1984, Ogólna teoria systemów. Podstawy, rozwój, zastosowania, PWN, Warszawa.

Butler R.W., 1980, The concept of a tourism area cycle of evolution: implications for the management of resources, Canadian Geographer, 24, 1, s. 5-12.

-, 2006a, The Tourism Area Life Cycle - Applications and Modifications, Channel View Publications, Clevedon.

-, 2006b, The Tourism Area Life Cycle - Conceptual and Theoretical Issues, Channel View Publications, Clevedon.

Chojnicki Z., 1988, Koncepcja terytorialnego systemu społecznego, Przegląd Geograficzny, 60, 4, s. 491-510.

Cooper C., Jackson S., 1989, Destination lifecycle: the Isle of Man case study, Annals of Tourism Research, 16, 2, s. 377-398.

Douglas N., 1997, Applying the lifecycle model to Melanesia, Annals of Tourism Research, 24, 1, s. 1-22.

Farrell B., Twinning-Ward L., 2005, Seven steps towards sustainability: Tourism in the context of new knowledge, Journal of Sustainable Tourism, 13, 1, s. 109-122. 
Hovinen G., 2001, Revisiting the destination lifecycle model, Annals of Tourism Research, 29, s. 209-230.

Kruczek Z., Zmyślony P., 2010, Regiony turystyczne, Proksenia, Kraków.

Liszewski S., Baczwarow M., 1998, Istota i wtaściwości przestrzeni rekreacyjno-turystycznej, Turyzm, 8, 1, s. 39-67.

Lundtorp S., Wanhill S., 2001, The resort lifecycle theory, Annals of Tourism Research, 29, 4, s. 947-964.

McDonald J. R., 2009, Complexity science: an alternative world view for understanding sustainable tourism development, Journal of Sustainable Tourism, 17, 3, s. 455-471.

Mc Kercher B., 1999, A chaos approach to tourism, Tourism Management, 20, 4, s. 425-434.

Oppermann M., 1998, What is new with the resort cycle?, Tourism Management, 19, 1, s. $169-180$.

Prigogine L., Stengers R., 1985, Order out of Chaos. Man's New Dialogue with Nature, Flamingo, London.

Russell R, Faulkner B., 1999, Movers and shakers: Chaos makers in tourism development, Tourism Management, 20, 4, s. 411-423.

-, 2004, Enterpreneurship, chaos and the tourism area lifecycle, Annals of Tourism Research, 31, 3, s. 556-579.

Szulc-Dąbrowiecka E., 2004, Farafra jako miejscowość turystyczna w latach 1993-2004, Afryka, Azja, Ameryka Łacińska, 81, s. 157-185.

Tempczyk M., 1998, Teoria chaosu a filozofia, Wydawnictwo Cis, Warszawa.

[Wpłynęło: luty; poprawiono: kwiecień 2011 r.]

\section{LUDWIK MAZURKIEWICZ}

\section{ON AN ATTEMPT AT APPLYING CHAOS THEORY IN DESCRIBING THE EVOLUTION OF A TOURISM AREA}

In its original version, the concept of the "life cycle" in an area attractive to tourists was concerned with a small seaside resort. However, in the contemporary literature on this subject, larger areas are also taken into consideration, being treated as products, since a market exists on which they are "sold". That market comprises all the tourists paying visits, spending their money on stays and taking advantage of benefits accruing from tourism attractions. With the passage of time, tourists' arrivals stimulate social and economic change that present a process resembling a "life cycle" in the given area. The intensity of the changes in question is measurable by reference to different variables (features), of which the main one is usually the number of tourists visiting, while others include the level of investment in tourism infrastructure, revenues in the tourism sector, the level of employment in this sector in the given area, the condition of the natural environment, the attitude of residents to tourists, and the pattern of land use. In its (market) life cycle, the area goes through six stages in succession, i.e. the stages of exploration, involvement, development, consolidation, stagnation and decline or rejuvenation.

At the stage of exploration, an area is visited by just a few tourists. There are simple and poor facilities to meet these peoples' needs and wants, but the environment is still 
clean and unspoiled for this reason. The local community is as yet unfamiliar with tourists and their ways, and its social and economic structures are still largely undisturbed by the influence of guests from outside.

At the stage of involvement, the number of tourists coming to the area increases. Arrivals mainly assume the form of either sightseeing tours to gain an acquaintance with valuable tourism features, or else short holidays. The time spent on stays is not long, however. The first facilities then appear to satisfy tourists' needs and wants. The tourism infrastructure is mainly modest, but nevertheless sufficient to attract local people into engaging with tourism. It sometimes emerges that the influence of both this infrastructure and the rising number of tourists on the natural environment as well as the social situation of the local community is beginning to seem uncomfortable, but it is not harmful as yet.

With the passage of time, the area is visited by a growing number of tourists, and the development stage begins. The numbers coming are at this point the greatest to be noted at any time in the area's life cycle. What attracts them is a still-clean and not overloaded environment and friendly people. The quickly rising numbers of tourists and increasing demand they generate attract businesspeople, who create tourism infrastructure. The rates at which numbers of entrepreneurs increase and the capacity of tourism infrastructure and employment in the tourism sector grow are higher at this point in the life cycle than at any other. However, the destructive influence on patterns of land use, the natural environment and social life is becoming ever-more discernible.

The stage of consolidation is then the time of full development of the tourism function in the area. But the rate of further development is declining and the area is losing some of its previous attractiveness, while other still fully-attractive destinations are coming into being. The number of tourists goes on increasing, but at a noticeably slower rate, the reason being the depletion of reserves of new land available for use and, on the other hand, negative effects of the influence of tourism on the natural environment and the life of the community.

In the stage of stagnation, the number of tourists levels off, as does that of investment activity. The infrastructural capacity for tourists does not develop either, while revenues due to tourism are growing smaller and smaller. The reason for this is a decline in the number of guests arriving. The further development of the tourism function is also arrested by the barrier a destroyed natural environment represents, as well as the increasing dissatisfaction of local people, who are more and more irritated by everyday inconveniences and the threats to the norms of social life tourists generate.

The stagnation stage changes sooner or later into one of decline. The most characteristic feature at this stage is a sustained decline in numbers of tourists, who are discouraged by prevailing conditions. Businesspeople now follow in the tracks of tourists seeking more attractive areas. Employment in the tourism sector grows ever smaller, the result being declining quality of life for local people, who begin to appreciate the benefits that tourism offered, and so change their attitude to it. With the passing of time the tendency to return to the previous situation increases, along with pressure on local authorities to strive to attract tourists and entrepreneurs. Often local people take tourism-sector activity into their own hands. Should appropriate steps be taken to favour investments or new tourism attractions, the stage of decline may change into one of rejuvenation. 
In essence, the theory of the life cycle of tourism areas is deterministic in nature. This is manifested in two ways. Firstly, changes having the form of consecutive stages always appear in the same order. The exit from any given stage determines the appearance of the next one, always in line with the same formula. Changes proceed in a quasi-linear fashion, and there is no assumption as to the possibility of any disturbance appearing that would alter the way the system, i.e. the tourism area, behaves. Secondly, the system's structure presents a macro scale. Only mass phenomena (composed of many elements) are taken into account, i.e. tourists, local people, entrepreneurs and tourism infrastructure. No influence of individual actors or other single factors is considered to act in an accidental manner, in such a way as to change the course of events. Such stimuli may appear at a micro scale, but this does not exist among the assumptions of the theory.

Every system related to a tourism area is by definition highly complex, and the theory of the tourism area life cycle is not therefore able to describe well what happens in reality. To make it a little more realistic, the paper proposes another theory, i.e. the theory of chaos that has been invented to describe and explain how complex system behave. Its assumptions are here introduced to the theory of the tourism area life cycle, and the latter in its new form is then applied in describing the process of development of one of Poland's resorts. 
http://rcin.org.pl 